\title{
ISTRAŽIVANJE UTJECAJA ČEKANJA STUDENATA NA PERCIPIRANU KVALITETU USLUGE NA PRIMJERU STUDENTSKE REFERADE
}

\author{
INVESTIGATING THE IMPACT OF WAITING TIME ON \\ THE PERCEIVED QUALITY OF SERVICE ON A STUDENT \\ ADMINISTRATION OFFICE EXAMPLE
}

SAŽETAK: Cilj ovoga rada je utvrditi utjecaj vremena čekanja studenata u studentskoj referadi na zadovoljstvo pruženom uslugom, tj. na percepciju kvalitete usluge te empirijski analizirati repove čekanja u studentskoj referadi. Istraživanje je provedeno ispred jedne studentske referade, na način da se bilježilo svaki dan u jednom tjednu po tri sata dnevno, svaki dan u isto doba dana. Dijelilo se anketne upitnike studentima koji su čekali svoj ulazak u referadu kako bi primili usluge referade. Prikupljeni su podatci o demografskim obilježjima ispitanika, vremenu čekanja provedenog u repu, na šalteru usluživanja, vremenu provedenom u uslužnom sustavu te zadovoljstvu uslugama. Rezultati istraživanja su testirani koristeći kvantitativne metode istraživanja te je u zaključku istraživanja vidljivo da postoji uloga vremena čekanja na zadovoljstvo uslugom, tj. na percepciju kvalitete usluge.

KLJUČNE RIJEČI: čekanje, red, rep, repovi čekanja, kvaliteta usluge.

\begin{abstract}
The aim of this work is to determine the influence of the student's waiting time in the student reference office on satisfaction with the provided service, i.e. on the perceived quality services, and empirically analyze waiting times in the student reference office. The research was conducted in front of a student reference office. Each day, during three hours a day, survey questionnaires was given to students who were waiting to receive student reference office services. Data on demographic characteristics of respondents, data on the waiting time spent in the tail and at the service counter, the time spent in the service system, and satisfaction with the services were collected. The results of the research
\end{abstract}


were tested using quantitative methods of research and in the conclusion of the research it is evident that there is a role of waiting time on the satisfaction of the service, i.e. on the perceived quality services.

KEYWORDS: waiting, queue, tail, queues, service quality.

\section{UVOD}

Repovi čekanja i njihov utjecaj na percipiranu kvalitetu usluge su krajem 20. stoljeća zadobili veliku pozornost kako u stručnim, tako i u znanstvenim krugovima. Glavni cilj ovoga rada je utvrditi utjecaj vremena čekanja studenata u studentskoj referadi na zadovoljstvo pruženom uslugom, tj. na percepciju kvalitete usluga studentske referade. U studentskim referadama se često pojavljuje problem repova čekanja, stoga su praktičan primjer na kojemu će detaljnije biti obrađeni svi aspekti repova čekanja vezani uz zadovoljstvo klijenata pruženim uslugama od strane uslužnih sustava. Tema je relevantna za obradu zbog učestalog manifestiranja čekanja u svakodnevnom životu i u poslovnim situacijama te zbog povećanja opsega uslužnih djelatnosti u ekonomskom okruženju, ali i zbog sve veće vrijednosti vremena za kupce. Riječ je o kompleksnom području koje uključuje percepcije osoba koje sudjeluju u čekanju usluge te njihovo mentalno stanje za vrijeme pružanja usluge. Čekanje je uobičajeno za usluge, stoga je poželjno dizajnirati uslužni sustav tako da čekanje bude usklađeno s očekivanim čekanjem, kako se kvaliteta usluge ne bi percipirala kao loša i neorganizirana.

Brojna uslužna poduzeća brinu o duljini repova čekanja jer vrijeme čekanja klijenata ima utjecaj na percepciju kvalitete pruženih usluga, stoga je vrijeme cijenjeno od strane uslužnih poduzeća, ali i od klijenata. Ako je vrijeme čekanja predugo, uslužna poduzeća mogu gubiti klijente, jer oni vrijeme čekanja smatraju žrtvom koju moraju proći da bi dobili uslugu (Bielen i Demoulin, 2007.). Stajanje u repu čekanja je izazovno za klijente zato što vrijeme smatraju oskudnim resursom (Zourrig i Chebat, 2009.). Glavna uloga koju ima proučavanje vremena čekanja u većini usluga vodi potrebi da se više pozornosti posvećuje poboljšanju razumijevanja načina na koji klijenti percipiraju, proračunavaju, konzumiraju i vrednuju vrijeme (Lovelock i Gummesson, 2004.). Menadžeri su odavno svjesni ovoga pitanja, stoga su mnoge strategije i praktična rješenja zamišljeni kako bi iskustvo čekanja bilo ugodnije ili da bi se barem smanjilo i izbjeglo nestrpljenje (Zourrig i Chebat, 2009.).

U radu će se staviti fokus na mjerenje percipirane kvalitete usluge u odnosu na čekanje budući da ta tema nije dovoljno istražena (Shi i dr., 2015.), a tiče se percepcija koje su subjektivne, dok se vrijeme čekanja objektivno mjerilo u svrhu da se vidi je li zaista čekanje umanjuje kvalitetu usluge u ovoj specifičnoj situaciji dobivanja usluge koju klijent nije u mogućnosti dobiti drugdje. Naime, prema istraživanju od (Hensley i Sulek, 2007.) dulje vrijeme čekanja snižavat će percipiranu kvalitetu usluge, ali prema istraživanju od (Jones i Peppiatt, 1996.), ako je klijentu usluga vrijedna on je više spreman čekati i ne umanjuje se percipirana kvaliteta usluge.

Rad je strukturiran tako da prvo daje pregled literature na temu uloge čekanja u zadovoljstvu pruženom uslugom, zatim se pokazuje metodologija istraživanja, potom rezultati i zaključak istraživanja. 


\section{ULOGA ČEKANJA U ZADOVOLJSTVU PRUŽENOM USLUGOM}

Negodovanje klijenata radi vremena čekanja je izrazito bitno jer ako klijent nije zadovoljan uslugom, on može otići konkurenciji i više se nikada ne vratiti ili se može žaliti drugima o niskoj kvaliteti usluge (Sarel i Marmorstein, 1998.). Čak do 27\% klijenata koji ne uspiju dobiti uslugu od strane pružatelja usluga odluče koristiti konkurentske usluge (Sheu, McHaney i Babbar, 2003.). Takve negativne percepcije klijenata o usluzi utječu na ugled i profitabilnost poduzeća (Davis i Maggard, 1990.). Klijenti često gledaju na čekanje kao na gubitak, tj. trošak vremena (Hensley i Sulek, 2007.). Danas klijenti imaju sve manje slobodnoga vremena, stoga su i manje tolerantni na repove čekanja u uslugama (Hensley i Sulek, 2007.), a pružatelji usluga su toga svjesni (Sheu, McHaney i Babbar, 2003.). Kada klijenti smatraju da je vrijeme čekanja predugo, postaju manje zadovoljni cjelokupnom kvalitetom usluge (Lee i Lambert, 2005.).

Zadovoljstvo vremenom čekanja ima umjereni učinak na povezanost između zadovoljstva uslugama i odanosti klijenata. Učinak zadovoljstva uslugama na odanost klijenata varira ovisno o zadovoljstvu vremenom čekanja. Pružatelji usluga koji očekuju uspostavu lojalnosti klijenata moraju dodatno povećati zadovoljstvo vremenom čekanja zbog utjecaja na zadovoljstvo uslugama (Bielen i Demoulin, 2007.). Jako zadovoljan klijent nastavit će tražiti uslugu u budućnosti te možda čak i povećati prihode kroz veću učestalost posjeta $i$ širenje pozitivnog iskustva drugima, no suprotno tome, nezadovoljan klijent će imati negativan utjecaj na prihod i dobit (Davis i Heineke, 1994.). Pawlowski (2016.) navodi da je moguće promijeniti iskustvo čekanja klijenata u redu u vrlo pozitivno iskustvo, a da bi poduzeća to uspjela moraju obratiti pozornost na osnovna načela psihologije čekanja.

Također, klijenti su spremni dulje čekati kada je zadovoljstvo uslugom visoko, nego kada je zadovoljstvo uslugom nisko te tada neće prihvatiti niti trpjeti dulje čekanje, zato što vrijeme čekanja smatraju potrebnom žrtvom za dobivanje visoke razine kvalitete usluge (Bielen i Demoulin, 2007.). Klijenti često moraju čekati tijekom procesa pružanja usluga, a obično se smatra da čekanje ima negativan utjecaj na ukupno zadovoljstvo uslugama (Zhao, Hou i Gilbert, 2014.). Stvarno vrijeme čekanja se definira kao vrijeme od dolaska klijenta u sustav do vremena početka pružanja usluge (Jones i Peppiatt, 1996.), a prethodi percipiranom vremenu čekanja, više nego što prethodi zadovoljstvu vremenom čekanja (Bielen i Demoulin, 2007.). Smanjivanje stvarnog vremena čekanja vodi većem zadovoljstvu uslugom (Davis i Heineke, 1994.). Kada klijenti imaju malo vremena za uslužni sustav, tada im se čini da vrijeme teče jako sporo, jer repovi čekanja u tom slučaju usporavaju vrijeme (Wexler, 2015.).

Percepcija stvarnog vremena čekanja se razlikuje od očekivanog vremena čekanja. Također, postoji jaz između stvarnog vremena čekanja i percipiranog vremena čekanja, a može iznositi i do 40\% (Jones, Peppiatt, 1996.). Percepcije klijenata mogu se mijenjati tako da se razlika između percipiranog i stvarnog vremena znatno smanji, a reduciranje tog jaza može, ali i ne mora voditi većem zadovoljstvu klijenata uslugom. Vjeruje se da je ljudska percepcija vremena čekanja iskrivljena, tako da većina klijenata smatra da su čekali dulje nego što stvarno jesu, no menadžeri imaju mogućnost promijeniti percepcije klijenata o vremenu koje su potrošili u redu (Jones i Peppiatt, 1996.). Zadovoljstvo klijenata temelji se na percepciji usluge, a ne na stvarnoj isporuci usluga (Jones i Peppiatt, 1996.). Menadžeri 
trebaju utvrditi kako zadovoljstvo klijenata čekanjem utječe na percepcije usluga (Hensley i Sulek, 2007.). Uzima se u obzir da je zadovoljstvo vremenom čekanja post-iskustvo, uključujući i kognitivne i afektivne aspekte čekanja te u kojoj mjeri percipirano vrijeme čekanja odgovara očekivanjima klijenata (Bielen i Demoulin, 2007.). Percipirano vrijeme čekanja utječe na kognitivnu dimenziju procjene čekanja, a kognitivne i afektivne dimenzije procjene vremena čekanja pozitivno utječu na zadovoljstvo uslugama (Bielen i Demoulin, 2007.).

Postoji izravna korelacija između duljine stvarnog vremena čekanja i zadovoljstva klijenata. Što klijenti dulje čekaju, tj. što je stvarno vrijeme čekanja dulje, to su oni manje zadovoljni s uslugom (Hensley i Sulek, 2007.), stoga treba uzeti u obzir da dolazak klijenta s dugim vremenom čekanja obeshrabruje njegov sljedeći dolazak (Mueller, 2000.). Ta korelacija nije konstantna, već varira ovisno o dobu dana, danu u tjednu te o vrsti usluge (Jones i Peppiatt, 1996.). Raspon sposobnosti ljudi da procjenjuju stvarno vrijeme čekanja je širok, tako da $17 \%$ klijenata procijeni vrlo točno vrijeme čekanja, a $10 \%$ potpuno netočno (Jones i Peppiatt, 1996.).

Što je kraće vrijeme čekanja, to klijenti više precjenjuju vrijeme čekanja, a razlog tome je što ispitanici obično navode svoju percepciju vremena čekanja u minutama, a ne u sekundama, tj. stvarnom vremenu čekanja. Klijenti u prosjeku precjenjuju vrijeme čekanja za 36\% (Durrande-Moreau, 1999.), a ta procijenjena, tj. precijenjena vremena čekanja imaju jednak, ako ne i veći učinak na zadovoljstvo od objektivnog vremena čekanja (McGuire i sur., 2010.).

Klijenti imaju različita očekivanja kada se radi o očekivanom vremenu čekanja, a ta su očekivanja kompleksna (Fullerton i Taylor, 2015.). Očekivano vrijeme čekanja ima veću važnost za klijenta, nego stvarno vrijeme čekanja (Jones i Peppiatt, 1996.), a povezuje ga se s vremenom čekanja prije ulaska u sustav (Durrande-Moreau, 1999.). Kada se stvarno vrijeme čekanja koje klijent očekuje ne može odrediti, ažuriranje ili izvješćivanje o stanju u unaprijed određenim intervalima može biti prihvatljiv supstitut, stoga klijente treba obavještavati o vremenu čekanja povremeno ili kada se dogodi neka promjena u sustavu čekanja. Upravljanjem očekivanjima klijenata o vremenu čekanja, povećava se zadovoljstvo klijenata uslugom (Davis i Heineke, 1994.). Percipirano vrijeme čekanja utječe na kognitivnu dimenziju procjene čekanja (Bielen i Demoulin, 2007.), tako da klijent koji očekuje da će kratko čekati, ako se to ne ispuni, negativno će reagirati naspram drugih klijenata u repu čekanja (Durrande-Moreau, 1999.). Kako se očekivano vrijeme čekanja povećava, zadovoljstvo klijenata se smanjuje, no to se može smanjiti zaokupljanjem korisnika koji čekaju. Očekivano vrijeme čekanja ovisi o stvarnom vremenu čekanja te o duljini reda, što daje naznaku vjerojatnog čekanja. Vrsta repa čekanja isto tako ovisi o očekivanom vremenu čekanja, tj. radi li se o jednom ili više repova čekanja. Klijenti koji uživaju u pruženoj usluzi i česti klijenti očekuju očekivano vrijeme čekanja kraćim, nego oni koji ne uživaju u usluzi i koji nisu česti klijenti. (Durrande-Moreau, 1999.).

Klijenti su tolerantniji prema duljem vremenu čekanja kada vide da je puno klijenata u sustavu (Hensley i Sulek, 2007.). Prethodna istraživanja ističu utjecaj informacija o čekanju i o trajanju čekanja na kognitivni i afektivni aspekt čekanja kada je čekanje dugo (Bielen i Demoulin, 2007.) te tijekom vremena velike potražnje (Bielen i Demoulin, 2007.). Kada je potražnja visoka i prelazi postojeće kapacitete, tj. kada usluga ne može pratiti dolaske, rep čekanja će se nastaviti povećavati sve dok se nešto ne napravi (Morse, 1963.) pa menadžeri moraju razmotriti promjenu obrasca potražnje ili kapaciteta opskrbe kako bi se usluga mo- 
gla isporučiti bez dugotrajnog čekanja za klijente (Sheu, McHaney i Babbar, 2003.), a to je moguće na način da dodaju nove resurse u uslužni sustav. Uslužna poduzeća mogu pokušati izgladiti potražnju na način da motiviraju klijente da dolaze u vremena slabije potražnje nudeći tada nižu cijenu usluga (Bielen i Demoulin, 2007.). U slučaju da se obrazac potražnje ne može mijenjati, menadžeri bi mogli razmotriti strategije usmjerene na kontrolu razine pružanja usluga, kao što je raspoređivanje povremenih radnika (Sheu, McHaney i Babbar, 2003.). Klijenti su tolerantniji prema duljem vremenu čekanja kada je usluga za njih vrijedna, tako da tolerancija na dugo čekanje za vrijednim uslugama omogućuje klijentima da usklade očekivano vrijeme čekanja sa stvarnim vremenom čekanja (Jones i Peppiatt, 1996.). Ne mora samo vrijednost dodijeljena usluzi biti ta koja će utjecati na percepciju korisnika, već i razina očekivanja koju klijenti mogu imati o vjerojatnosti čekanja (Jones i Peppiatt, 1996.). Na očekivano čekanje može utjecati i raspoloženje klijenata te stavovi klijenata koji mogu biti vrlo različiti ovisno o njihovim iskustvima (Jones i Peppiatt 1996.). Tolerancija na vrijeme čekanja se razlikuje i prema kulturalnim skupinama (Jones i Peppiatt, 1996.).

Iz navedenoga istraživanja literature, a posebice iz istraživanja od (Hensley i Sulek, 2007.), može se zaključiti da će dulje vrijeme čekanja snižavati percipiranu kvalitetu usluge. Međutim, prema istraživanju od (Jones i Peppiatt, 1996.), ako je klijentu usluga vrijedna on je više spreman čekati što je ujedno specifična situacija repova čekanja u studentskoj referadi. Naime, student nema alternativni izvor usluge ili konkurentsku uslugu koju bi mogao koristiti, nego je primoran strpljivo čekati u redu da obavi svoje studentske dužnosti. Stoga je očekivano da će studentima ova usluga biti važna i da su time više voljni čekati i percipirati uslugu kao pozitivnu usprkos nalazima (Hensley i Sulek, 2007.) da povećanjem vremena čekanja percepcija kvalitete opada. Stoga se postavlja hipoteza ovoga rada da vrijeme čekanja neće utjecati na percipiranu kvalitetu usluge suprotno istraživanju (Hensley i Sulek, 2007.), a u skladu s istraživanjem od (Jones i Peppiatt, 1996.).

H1: Vrijeme čekanja usluge neće utjecati na percepciju kvalitete ako je usluga za klijenta važna.

U ovome radu koriste se teorijska saznanja o repovima čekanja (Heizer, Render i Munson, 2017.). Kvantitativno modeliranje repova čekanja započelo je 70-ih godina prošloga stoljeća i glavna zadaća istraživača bila je kako s postojećim ili čak manjim resursima smanjiti vrijeme čekanja klijenata. Tako primjerice, Jouini i dr. (2008.) dokazuju da ako svi agenti rade sve poslove iskorištenost agenata se ravnomjerno raspoređuje i moguće je odgovoriti na više poziva u odnosu na situaciju kada je agent osposobljen samo za jedan posao. Fitzsimmons i Fitzsimmons (2008.) pak pokazuju da u situaciji kada je $n$ istovjetnih servera, a samo jedan red postiže se $30 \%$ veća efikasnost, nego kad je više redova na više servera. U takvom slučaju govori se o modelu jednog reda $\mathrm{n}$ istovjetnih servera. Prema Fitzsimmons i Fitzsimmons (2008.) se onda mogu koristiti formule za n servera, ali osnovnog modela repa čekanja. Naravno da taj model ima neke pretpostavke koje treba provjeriti prije korištenja formula za proračun operativnih obilježja repa čekanja, a to su:

- Dolasci su slučajni i ponašaju se po Poissonovoj raspodjeli

- Vrijeme usluživanja ponaša se po eksponencijalnoj raspodjeli

- Klijenti dolaze iz neograničene populacije

- Pravilo posluživanja je po načelu prvi došao prvi poslužen. 
Prema Shi i dr. (2015.) ovaj osnovni model pomaže da se naprave simulacije i predlože bolja operativna rješenja od slučaja do slučaja. Oni su promatrali tijekom 6 mjeseci zajedno s grupom zaposlenika od medicinskih sestara do upravitelja bolnice da se zaista grupiranjem resursa (engl. pooling of resources) mogu postići bolje operativne performanse u repu čekanja, tj. u njihovome slučaju u većem broju odgovorenih poziva. Međutim, ono što Shi i dr. (2015.) naglašavaju, a to je da je glavna tema u proučavanju repova čekanja s akademske perspektive u smanjenju operativnih troškova dok je utjecaj čekanja na kvalitetu usluge potpuno zanemaren. Zbog toga će se u ovome radu prvo provjeriti jesu li zadovoljene pretpostavke modela repa čekanja kako bi se mogle iskoristiti formule za proračun operativnih obilježja repa čekanja, a onda usmjeriti pozornost na vezu između čekanja i zadovoljstva klijenata u svrhu potvrđivanja hipoteze H1.

\section{METODOLOGIJA ISTRAŽIVANJA}

Istraživanje je provedeno ispred studentske referade na Ekonomskom fakultetu u Zagrebu u tjednu 26. 6. 2017. - 30. 6. 2017., na način da je autor svaki dan u navedenom tjednu po tri sata dnevno, svaki dan u isto doba dana, dijelio anketne upitnike studentima koji su čekali svoj ulazak u referadu kako bi dobili usluge referade. Ispitivač je pri dolasku i odlasku bilježio trenutne brojeve koji primaju usluge u referadi, a koji su prikazani na dva displeja u hodniku iznad ulaznih vrata referade, kako bi se znalo koliko je klijenata došlo i prošlo kroz uslužni sustav, što je služilo i kao kontrola mjerenja. Prostor za čekanje ispred referade ne nudi dovoljno mjesta za sjedenje, dosta je mračan, hladan te nema nikakvih dodatnih materijala koji bi mogli zaokupiti studente dok čekaju.

Anketni upitnik se sastojao od deset pitanja vezanih uz demografska obilježja ispitanika, vrijeme čekanja te zadovoljstvo uslugom, a ispitanici su samostalno popunjavali upitnike. Ispitivač je osobno dijelio i prikupljao upitnike te poticao sudjelovanje ispitanika. U anketnom upitniku su korištene nominalne, intervalne i omjerne skale mjerenja, a pitanja su bila otvorenoga i zatvorenoga tipa.

Odabrana je studentska referada na Ekonomskom fakultetu radi velikog broja studenata koji na dnevnoj bazi koriste usluge referade. Referada pruža različite usluge svojim klijentima, kao što su npr., pružanje informacija o različitim smjerovima studija, primanje dokumenata za upis studenata u više godine studija, ovjeravanje indeksa, promjena smjerova studiranja, rješavanje zamolbi i slično.

Studenti kada dođu kod referade, da bi dobili uslugu, prvo trebaju odabrati tip studija i uzeti broj s redomata. Na papiriću koji izađe iz redomata dostupni su podatci o lokaciji redomata, odabranome studiju, datumu, vremenu uzimanja papirića, jedinstvenom broju usluživanja te broju klijenata u redu na hrvatskome i na engleskome jeziku. Podatci o broju klijenata u redu su korisni klijentima jer u tome trenutku mogu procijeniti koliko će otprilike čekati za svoju uslugu te odlučiti hoće li ostati čekati u redu ili će odustati jer smatraju da bi predugo čekali. Nakon što uzmu broj s redomata čekaju da se njihov broj skupa s brojem šaltera usluživanja pojavi na oba displeja u hodniku iznad ulaznih vrata u referadu te tada ulaze u referadu i koriste uslugu. Iznad redomata nalazi se A4 papir na kojemu su isprintana uputstva za korištenje redomata: 
1. Uzmite broj za odgovarajući studij

2. Pratite na displeju koji šalter zove Vaš broj (̌̌alteri od 1 - 6)

3. Kada uđete u referadu, idete na šalter koji vas je zvao

o Jedan broj vrijedi za jedan indeks, ukoliko imate više indeksa morate uzeti isto toliko brojeva

o Ukoliko ste iz, nekog razloga zakasnili na pozivanje Vašeg broja morate uzeti novi broj

$>$ Jedan indeks $=$ jedan broj.

Osim uputstava za korištenje redomata, također je prisutna i obavijest o radnom vremenu redomata:

1. Ponedjeljak $\rightarrow$ 08:00 - 15:00

2. Utorak $\rightarrow$ 08:00 - 18:00

3. Srijeda $\rightarrow$ 08:00 - 15:00

4. Četvrtak $\rightarrow$ 08:00 - 18:00

5. Petak $\rightarrow$ 08:00 - 14:30.

Radno vrijeme studentske referade za rad sa studentima:

1. Ponedjeljak $\rightarrow 11: 30-15: 30$

2. Utorak $\rightarrow$ 11:30 - 15:30 (dežurstvo 15:30 - 18:30)

3. Srijeda $\rightarrow 11: 30-15: 30$

4. Četvrtak $\rightarrow$ 11:30 - 15:30 (dežurstvo 15:30 - 18:30)

5. Petak $\rightarrow$ 11:00 - 15:00.

Na redomatu je moguće odabrati jednu od četiri ponuđene opcije:
A. Stručni studij
B. Preddiplomski studij
C. Diplomski studij
D. Ostalo.

\section{REZULTATI ISTRAŽIVANJA}

Po prikupljenim podacima učinila se osnovna provjera ponaša li se dolazak klijenata po Poissonovoj raspodjeli, a vremena usluživanja po eksponencijalnoj raspodjeli i zaista ove dvije pretpostavke su potvrđene, što je bilo i za očekivati jer su već provedena brojna mjerenja koja pokazuju da se tako uobičajeno distribuiraju dolasci i posluživanje u uslugama (Heizer, Render i Munson, 2017.). Treća pretpostavka bila je da klijenti dolaze iz neograničene populacije. Ova pretpostavka se može smatrati zadovoljenom budući da prema mrežnim stranicama fakulteta na Ekonomskom fakultetu u Zagrebu studira preko 10.000 studenata. Četvrta pretpostavka je zadovoljena budući da prostoji redomat koji dijeli listice upravo po načelu prvi došao, prvi poslužen.

Prvo će se provjeriti operativne karakteristike reda u 5 dana mjerenja, a zatim će se nezavisno prikazati rezultati o percipiranoj kvaliteti usluge na temelju njihovog percipiranog čekanja. 
Iz tablice 1. se može uočiti da je najveći broj opažanja prikupljen u četvrtak, 29. 6. 2017., kada su prikupljeni podatci o pružanju usluga 73 klijenta. Najmanji broj opažanja je prikupljen u srijedu, 28. 6. 2017., kada su prikupljeni podatci o pružanju usluga 53 klijenta.

Tablica 1. Broj prikupljenih opažanja po datumima promatranja

\begin{tabular}{|c|c|}
\hline Datum & Broj opažanja \\
\hline 26. 6. 2017. & 64 \\
\hline 27. 6. 2017. & 58 \\
\hline 28. 6. 2017. & 53 \\
\hline 29.6.2017. & 73 \\
\hline 30. 6. 2017. & 58 \\
\hline
\end{tabular}

Fokus istraživanja u terminima obuhvata istraživanja je uzak, no potrebni podatci su prikupljeni od većeg broja ispitanika. Ispitanici su isključivo objekti istraživanja na kojima se provjeravaju hipoteze te se nastojao što više smanjiti istraživačev utjecaj. Mišljenje, pogledi i stajališta istraživača odražavaju se u polaznim pretpostavkama i odabiru problema, ali ne i u metodi, analizi, iznošenju rezultata te njihovu tumačenju. U radu su korištene metode grafičkog i tabličnog prikazivanja te distribucije vjerojatnosti. Metodama grafičkog i tabličnog prikazivanja prikazan je rad studentske referade Ekonomskog fakulteta u Zagrebu prema danima. Distribucija vjerojatnosti predstavlja omjer ishoda s odabranim obilježjem u ukupnom broju ishoda. Analiza je rađena u statističkom programu STATISTICA 12.

Iz dvodimenzionalnoga prikaza u tablici 2. može se uočiti da u svim promatranim danima preko $90 \%$ ispitanika nije čekalo za redomat. U petak, 30. 6. 2017., nitko nije čekao za redomat, što znači da su svi ispitanici odmah bili u mogućnosti uzeti broj za ulazak u referadu.

Tablica 2. Struktura uzorka prema čekanju za redomat po datumima promatranja

\begin{tabular}{|c|c|c|c|}
\hline \multirow{2}{*}{ Datum } & \multicolumn{2}{|c|}{ PRISUTNOST ČEKANJA ZA REDOMAT } & \multirow{2}{*}{ Red - Ukupno } \\
\cline { 2 - 3 } & $\mathbf{d a}$ & 58 & 64 \\
\hline 26. 6. 2017. & 6 & $90,63 \%$ & $100 \%$ \\
\hline & $9,38 \%$ & 57 & 58 \\
\hline 27. 6. 2017. & 1 & $98,28 \%$ & $100 \%$ \\
\hline & $1,72 \%$ & 52 & 53 \\
\hline 28. 6. 2017. & 1 & $98,11 \%$ & $100 \%$ \\
\hline & $1,89 \%$ & 72 & 73 \\
\hline 29. 6. 2017. & 1 & $98,63 \%$ & $100 \%$ \\
\hline & $1,37 \%$ & 58 & 58 \\
\hline 30. 6. 2017. & 0 & $100,00 \%$ & $100 \%$ \\
\hline & $0,00 \%$ & $\mathbf{2 9 7}$ & $\mathbf{3 0 6}$ \\
\hline Ukupno & $\mathbf{9}$ & & \\
\hline
\end{tabular}


Iz tablice 3. može se uočiti da je samo drugi dan promatranja, 27. 6. 2017., bilo pet otvorenih šaltera za pružanje usluga, dok je ostalih dana bilo otvoreno po tri šaltera.

Tablica 3. Struktura uzorka prema broju šaltera usluživanja po datumima promatranja

\begin{tabular}{|c|c|c|c|c|c|c|}
\hline \multirow{2}{*}{ Datum } & \multicolumn{5}{|c|}{ BROJ ŠALTERA USLUŽIVANJA } & \multirow{2}{*}{$\begin{array}{c}\text { Red - } \\
\text { Ukupno }\end{array}$} \\
\cline { 2 - 6 } & $\mathbf{2}$ & $\mathbf{3}$ & $\mathbf{4}$ & $\mathbf{5}$ & $\mathbf{6}$ & 64 \\
\hline $\mathbf{2 6 . 6 . 2 0 1 7 .}$ & 0 & 19 & 25 & 20 & 0 & $100 \%$ \\
\hline & $0,00 \%$ & $29,69 \%$ & $39,06 \%$ & $31,25 \%$ & $0,00 \%$ & 58 \\
\hline $\mathbf{2 7 . 6 . 2 0 1 7 .}$ & 12 & 21 & 22 & 1 & 2 & $100 \%$ \\
\hline & $20,69 \%$ & $36,21 \%$ & $37,93 \%$ & $1,72 \%$ & $3,45 \%$ & 53 \\
\hline $\mathbf{2 8 . 6 . 2 0 1 7 .}$ & 15 & 21 & 17 & 0 & 0 & $100 \%$ \\
\hline & $28,30 \%$ & $39,62 \%$ & $32,08 \%$ & $0,00 \%$ & $0,00 \%$ & 73 \\
\hline $\mathbf{2 9 . 6 . 2 0 1 7 .}$ & 21 & 25 & 27 & 0 & 0 & $100 \%$ \\
\hline & $28,77 \%$ & $34,25 \%$ & $36,99 \%$ & $0,00 \%$ & $0,00 \%$ & 58 \\
\hline $\mathbf{3 0 . 6 . 2 0 1 7 .}$ & 7 & 34 & 17 & 0 & 0 & $100 \%$ \\
\hline & $12,07 \%$ & $58,62 \%$ & $29,31 \%$ & $0,00 \%$ & $0,00 \%$ & $\mathbf{3 0 6}$ \\
\hline
\end{tabular}

Iz dvodimenzionalnoga prikaza u tablici 4. može se uočiti da je u svim promatranim danima razina zadovoljstva uslugama studentske referade bila izvrsna.

Tablica 4. Struktura uzorka prema zadovoljstvu uslugom na datum promatranja

\begin{tabular}{|c|c|c|c|c|c|c|}
\hline \multirow{2}{*}{ Datum } & \multicolumn{5}{|c|}{ ZADOVOLJSTVO USLUGOM DANAS OD 1 - 5} & \multirow{2}{*}{$\begin{array}{c}\text { Red - } \\
\text { Ukupno }\end{array}$} \\
\hline & 1 & 2 & 3 & 4 & 5 & \\
\hline \multirow[t]{2}{*}{ 26. 6. 2017.} & 0 & 1 & 6 & 16 & 41 & 64 \\
\hline & $0,00 \%$ & $1,56 \%$ & $9,38 \%$ & $25,00 \%$ & $64,06 \%$ & $100 \%$ \\
\hline \multirow[t]{2}{*}{ 27. 6. 2017.} & 1 & 2 & 3 & 10 & 42 & 58 \\
\hline & $1,72 \%$ & $3,45 \%$ & $5,17 \%$ & $17,24 \%$ & $72,41 \%$ & $100 \%$ \\
\hline \multirow[t]{2}{*}{ 28. 6. 2017.} & 3 & 0 & 5 & 18 & 27 & 53 \\
\hline & $5,66 \%$ & $0,00 \%$ & $9,43 \%$ & $33,96 \%$ & $50,94 \%$ & $100 \%$ \\
\hline \multirow[t]{2}{*}{ 29. 6. 2017.} & 3 & 4 & 7 & 8 & 51 & 73 \\
\hline & $4,11 \%$ & $5,48 \%$ & $9,59 \%$ & $10,96 \%$ & $69,86 \%$ & $100 \%$ \\
\hline \multirow[t]{2}{*}{ 30. 6. 2017.} & 1 & 0 & 2 & 9 & 45 & 57 \\
\hline & $1,75 \%$ & $0,00 \%$ & $3,51 \%$ & $15,79 \%$ & $78,95 \%$ & $100 \%$ \\
\hline Ukupno & 8 & 7 & 23 & 61 & 206 & 305 \\
\hline
\end{tabular}

Općenito zadovoljstvo uslugom je ispitivano samo na dane 29. 6. 2017. i 30. 6. 2017., kada je u oba promatrana dana najveći broj ispitanika iskazao razinu ukupnog zadovoljstva vrlo dobrom, kao što je prikazano u tablici 5. 
Tablica 5. Struktura uzorka prema zadovoljstvu uslugom općenito na datum promatranja

\begin{tabular}{|c|c|c|c|c|c|c|}
\hline \multirow{2}{*}{ Datum } & \multicolumn{5}{|c|}{$\begin{array}{l}\text { ZADOVOLJSTVO USLUGOM OPĆENITO OD } \\
1-5\end{array}$} & \multirow{2}{*}{$\begin{array}{l}\text { Red - } \\
\text { Ukupno }\end{array}$} \\
\hline & $\mathbf{1}$ & 2 & 3 & 4 & 5 & \\
\hline \multirow[t]{2}{*}{ 29. 6. 2017.} & 1 & 14 & 21 & 22 & 15 & 73 \\
\hline & $1,37 \%$ & $19,18 \%$ & $28,77 \%$ & $30,14 \%$ & $20,55 \%$ & $100 \%$ \\
\hline \multirow[t]{2}{*}{ 30. 6. 2017.} & 0 & 6 & 25 & 16 & 10 & 57 \\
\hline & $0,00 \%$ & $10,53 \%$ & $43,86 \%$ & $28,07 \%$ & $17,54 \%$ & $100 \%$ \\
\hline Ukupno & 1 & 20 & 46 & 38 & 25 & 130 \\
\hline
\end{tabular}

Iz tablice 6. može se uočiti da je prosječno iskazano zadovoljstvo uslugom na dan pružanja usluge visoko te se razina zadovoljstva kreće u rasponu od 4,25 do 4,70.

Tablica 6. Prosječno zadovoljstvo uslugom na datum promatranja

\begin{tabular}{|c|c|c|c|}
\hline \multirow{2}{*}{ Datum } & \multirow{2}{*}{$\mathbf{n}$} & ZADOVOLJSTVO USLUGOM DANAS OD 1 - 5 \\
\cline { 3 - 4 } & & Prosjek & Standardna devijacija \\
\hline 26. 6. 2017. & 64 & 4,52 & 0,73 \\
\hline 27. 6. 2017. & 58 & 4,55 & 0,88 \\
\hline 28. 6. 2017. & 53 & 4,25 & 1,04 \\
\hline 29. 6. 2017. & 73 & 4,37 & 1,12 \\
\hline 30. 6. 2017. & 57 & 4,70 & 0,71 \\
\hline
\end{tabular}

Iz tablice 7. može se uočiti da se prosječno čekanje u repu kreće u rasponu od 0,23 do 0,66 minuta.

Tablica 7. Prosječno vrijeme čekanja provedeno u repu čekanja na datum promatranja

\begin{tabular}{|c|c|c|c|}
\hline \multirow{2}{*}{ Datum } & \multirow{2}{*}{$\mathbf{n}$} & \multicolumn{2}{|c|}{ ČEKANJE U REPU } \\
\cline { 3 - 4 } & & Prosjek & Standardna devijacija \\
\hline 26. 6. 2017. & 64 & 0,66 & 1,09 \\
\hline 27. 6. 2017. & 58 & 0,43 & 0,75 \\
\hline 28. 6. 2017. & 53 & 0,23 & 0,58 \\
\hline 29. 6. 2017. & 73 & 0,37 & 0,87 \\
\hline 30. 6. 2017. & 57 & 0,49 & 0,98 \\
\hline
\end{tabular}

Iz tablice 8. može se uočiti da su na datum 26. 6. 2017. studenti anketirani anketnim upitnikom u 169 minuta promatranja proveli 163 minute u uslužnom sustavu koji je radio kroz 3 pružatelja usluga. Anketirani studenti su ukupno čekali 121 minutu na šalteru, dok su u repu čekali ukupno 42 minute. Dakle, u uslužni sustav je u prosjeku dolazilo 0,38 studenata u svakoj minuti promatranja odnosno približno svake 3 minute je dolazio jedan student. Međutim, broj dolazaka nije ravnomjerno raspoređen, zbog čega dolazi do problema stajanja u repu. Vjerojatnost čekanja u repu je omjer čekanja u repu i čekanja u sustavu koji 
se sastoji od čekanja u repu i čekanja na šalteru te je jednaka 0,26. Budući da je vjerojatnost čekanja u repu veća od 0,10, dok broj studenata ne raste u beskonačnost, primjereno je koristiti Poissonovu distribuciju vjerojatnosti. Prema Poissonovoj distribuciji vjerojatnosti, vjerojatnost da niti jedan od pet slučajno odabranih studenata neće čekati u repu je 0,23 , dok je vjerojatnost da će u redu čekati barem jedan od pet slučajno odabranih studenata 0,77. Riječ je o visokoj vjerojatnosti, s obzirom da je veća od 0,50.

Tablica 8. Operativne karakteristike studentske referade u promatranom razdoblju

\begin{tabular}{|l|r|r|r|r|r|r|}
\hline \multicolumn{1}{|c|}{ Datum } & $\begin{array}{r}\text { 26. 6. } \\
\text { 2017. }\end{array}$ & $\begin{array}{r}\text { 27. 6. } \\
\text { 2017. }\end{array}$ & $\begin{array}{r}\text { 28. 6. } \\
\text { 2017. }\end{array}$ & $\begin{array}{r}\text { 29. 6. } \\
\text { 2017. }\end{array}$ & $\begin{array}{r}\text { 30. 6. } \\
\text { 2017. }\end{array}$ & Prosjek \\
\hline ukupan broj minuta testiranja & 169 & 169 & 169 & 168 & 165 & 168 \\
\hline ukupan broj šaltera usluživanja & 3 & 5 & 3 & 3 & 3 & 3,4 \\
\hline $\begin{array}{l}\text { ukupno vrijeme čekanja } \\
\text { provedeno u uslužnom sustavu } \\
\text { (minute) }\end{array}$ & 163 & 140 & 99 & 152 & 136 & 138 \\
\hline $\begin{array}{l}\text { ukupno vrijeme čekanja } \\
\text { provedeno na šalteru (minute) }\end{array}$ & 121 & 115 & 87 & 125 & 108 & 111,2 \\
\hline $\begin{array}{l}\text { ukupno vrijeme čekanja } \\
\text { provedeno u repu (minute) }\end{array}$ & 42 & 25 & 12 & 27 & 28 & 26,8 \\
\hline ukupan broj obrađenih dolazaka & 64 & 58 & 53 & 73 & 58 & 61,2 \\
\hline $\begin{array}{l}\text { prosječan broj obrađenih } \\
\text { dolazaka po minuti u uslužnom } \\
\text { sustavu }\end{array}$ & 0,38 & 0,41 & 0,31 & 0,43 & 0,35 & 0,365 \\
\hline vjerojatnost čekanja u repu & 0,26 & 0,18 & 0,12 & 0,18 & 0,21 & 0,19 \\
\hline $\begin{array}{l}\text { vjerojatnost ne čekanja u repu } \\
\text { kod pet slučajnih dolazaka }\end{array}$ & 0,23 & 0,37 & 0,52 & 0,38 & 0,32 & 0,364 \\
\hline $\begin{array}{l}\text { vjerojatnost da će klijent čekati } \\
\text { barem jedan od pet dolazaka }\end{array}$ & 0,77 & 0,63 & 0,48 & 0,62 & 0,68 & 0,636 \\
\hline
\end{tabular}

Ukupan broj minuta testiranja svaki dan je iznosio između 165 i 169 minuta te je svaki dan u funkciji bilo 3 šaltera, osim u utorak kada je bilo otvoreno čak 5 šaltera usluživanja, no od tih 5 šaltera dva su radila kratko vrijeme promatranja. Broj poslužitelja u studentskoj referadi je optimalan, stoga uspješno uravnotežuje vrijeme čekanja studenata i troškove fakulteta za šalterske službenike, tako da nema potrebe za povećanjem broja servera jer bi ionako većinu vremena bili neiskorišteni. Studenti su sveukupno najviše vremena čekajući u uslužnom sustavu proveli u ponedjeljak, 26. 6. 2017., točnije 163 minute, a najmanje u srijedu, 28. 6. 2017., kada su čekali sveukupno 99 minuta. Na šalteru su studenti čekajući proveli najviše vremena u četvrtak, 29. 6. 2017., točnije 125 minuta, a najmanje u srijedu 28. 6. 2017., kada su čekali 87 minuta. Ukupno vrijeme čekanja provedeno u repu bilo je najveće u ponedjeljak, 26. 6. 2017., a iznosilo je 42 minute, dok je najmanje bilo u srijedu, 28. 6. 2017., sa sveukupno 12 minuta provedenih u repu čekanja. Ukupan broj obrađenih dolazaka je bio najveći u četvrtak, 29. 6. 2017. te je iznosio 73 anketirana studenta, dok je najmanji bio u srijedu, 28. 6. 2017., s 53 anketirana studenta. Prosječan broj obrađenih dolazaka po minuti 
u uslužnom sustavu bio je najviši u četvrtak, 29. 6. 2017., s 0,43 anketirana studenta, a najmanji u srijedu, 28. 6. 2017. s 0,31 anketirana studenta u minuti promatranja. Vjerojatnost čekanja u repu je bila najviša u ponedjeljak, 26. 6. 2017., a iznosila je 0,26, dok je najmanja bila u srijedu, 28. 6. 2017. te je tada iznosila 0,12. Vjerojatnost ne čekanje u repu kod pet slučajnih dolazaka bila je najveća u srijedu, 28. 6. 2017. kada je iznosila 0,52, a najmanja u ponedjeljak, 26. 6. 2017., kada je iznosila 0,23. Vjerojatnost da će čekati barem jedan od pet studenata je bila najveća u ponedjeljak, 26. 6. 2017. te je iznosila 0,77 , a najmanja je bila u srijedu 28. 6. 2017., kada je iznosila 0,48. Zadovoljstvo pruženom uslugom bilo je najmanje u srijedu 28. 6. 2017 kada je prosječna ocjena iznosila 4,25, a najveća u petak 30. 6. 2017. kada je ona iznosila 4,70.

Tablica 9. Prosječna ocjena zadovoljstva i čekanje u minutama

\begin{tabular}{|c|c|c|}
\hline Datum & Prosječna ocjena zadovoljstva & Čekanje u minutama \\
\hline 26. 6. 2017. & 4,52 & 0,66 \\
\hline 27. 6. 2017. & 4,55 & 0,43 \\
\hline 28. 6. 2017. & 4,25 & 0,23 \\
\hline 29. 6. 2017. & 4,37 & 0,37 \\
\hline 30. 6. 2017. & 4,7 & 0,49 \\
\hline
\end{tabular}

Temeljem ovih podataka izvršena je regresijska analiza koja pokazuje jaku regresijsku vezu između čekanja i zadovoljstva uslugom. Koeficijent regresije je $\mathrm{R}=0,686$, koeficijent determinacije iznosi $\mathrm{R}^{2}=47 \%$. Drugim riječima $47 \%$ zadovoljstva uslugom determinirano je vremenom čekanja dok su ostalih $43 \%$ zadovoljstva uslugom determinirani drugim faktorima. Ipak, model je nesignifikantan $(\mathrm{p}=0,201)$.

Dakle, ovim velikim korelacijskim koeficijentom donekle se potvrđuju rezultati (Hensley i Sulek, 2007.) da postoji kauzalna veza između čekanja i percipirane kvalitete usluge, ali budući da je model nesignifikantan njihova nalaženja se ne mogu potvrditi u ovome radu. Budući da je ova usluga klijentima važna, onda se ova nesignifikantnost možda može objasniti u skladu s istraživanjem od (Jones i Peppiatt, 1996.) da percipirana kvaliteta usluge ne opada s čekanjem za vrijedne usluge.

Temeljem rezultata istraživanja može se vidjeti da su sve pretpostavke zadovoljene. Broj aktivnih poslužitelja je veći od jedan, tj. svaki dan su u prosjeku bila tri aktivna poslužitelja. Broj faza kroz koje student prolazi da bi primio uslugu iznosi jedan, s obzirom da je dovoljan jedan poslužitelj koji će pružiti uslugu studentu, a ne više njih kao što je npr., slučaj u bolnicama s medicinskim sestrama i doktorima. Poissonova distribucija dolazaka znači da su dolasci studenata slučajni. Distribucija vremena usluživanja je eksponencijalna. Populacija je neograničena, jer obuhvaća studente koji pohađaju Ekonomski fakultet u Zagrebu, ali i one koji ne pohađaju. Pravilo tko prvi dođe, taj bude i prvi uslužen je zadovoljeno, jer svaki student prilikom dolaska treba uzeti broj s redomata kako bi bio u mogućnosti primiti usluge studentske referade, tako da nije bilo nepravilnosti u uslužnom sustavu, što je jedan od ključnih razloga zadovoljstva studenata uslugama referade. Međutim, tu odmah treba spomenuti i ograničenja istraživanja. Glavno ograničenje istraživanja predstavlja činjenica da su podatci prikupljani svakodnevno u određeno doba dana u samo jednom tjednu, 26. 6. 2017. - 30. 6. 2017., stoga nisu reprezentativni te bi za reprezentativne podatke trebalo 
svakodnevno mjeriti vrijeme čekanja minimalno šest mjeseci kako bi se uhvatila veća vršna opterećenja npr., prilikom upisa. U radu od Shi i dr. (2015.) mjerenja su vršena preko šest mjeseci i bili su uključeni i sami djelatnici u istraživanje. Drugo ograničenje je da nisu svaki dan bili u funkciji svi poslužitelji. Npr., drugi dan istraživanja, 27. 6. 2017., u tri sata istraživanja, sveukupno je bilo otvoreno čak pet šaltera usluživanja, no šalteri broj pet i šest su bili u funkciji samo kratko vrijeme promatranja, stoga je autor uzeo u obzir prosječan broj poslužitelja, što predstavlja još jedno ograničenje kod korištenja formula za izračun vjerojatnosti. Kako bi mjerenje bilo reprezentativno treba paziti na to da je u funkciji usluživanja uvijek jednak broj šaltera usluživanja. Treće ograničenje je da je vršila mjerenja samo jedna osoba pa nije bilo moguće anketiranje svih pridošlih klijenata u sustav zbog njihove dinamike dolazaka u uslužni sustav. Bilo je potrebe za asistencijom u istraživanju, no do toga nije uspjelo doći, tako da su operativne karakteristike izračunate uz pomoć vjerojatnosti, umjesto uz pomoć formula za model jedan red, više servera.

Dobiveni rezultati su prikladni za donošenje indikativnih zaključaka, no za stvaranje potpune slike bilo bi potrebno provesti istraživanje na većem broju klijenata u drugim studentskim referadama.

Ipak ako se uzme prosjek zadovoljstvo studenata uslugom referade u odnosu na percipirano čekanje ono iznosi visokih 4,5 na ljestvici od 1 - 5 te ako se uzmu u obzir operativne karakteristike za ovih 5 dana mjerenja, onda se može zaključiti da su uz postojeći broj servera sve potrebe studenata zadovoljene s visokom ocjenom od 4,5.

\section{ZAKLJUČAK}

Repovi čekanja se pojavljuju u svakodnevnome životu i u poslovnim situacijama, a razlog pojavljivanja je taj jer uslužni sustavi ne mogu zadovoljiti potražnju za uslugom koju nude, tj. nemaju sposobnost bavljenja svim zahtjevima koji se stavljaju pred njih. Sveprisutno povećanje uslužnih djelatnosti u gospodarskom okruženju vodi povećanoj vrijednosti vremena za kupce, stoga je upravljanje vremenom čekanja klijenata izrazito bitna strategija tržišnog natjecanja. Nijedan aspekt uslužnoga sustava nije bitniji od čekanja na uslugu jer je čekanje prva interakcija u slijedu iskustava koje klijenti imaju u susretu s poduzećima. U radu se prikazuje važnost uloge čekanja na percepciju kvalitete pruženih usluga od strane uslužnih sustava.

Opseg i raznolikost repova čekanja su vrlo različiti od usluge do usluge, a zanimljiva je mogućnost povezivanja duljine čekanja usluge s percepcijom kvalitete usluge, na što je ovaj rad prije svega i usmjeren. Reakcije klijenata na čekanje mogu biti negativne, ali i pozitivne. Pozitivne reakcije čekanja se odnose na ugodna čekanja, kada klijenti mogu doživjeti prednosti pridruživanja grupi ljudi koji također čekaju. Prema tome, uslužni objekti trebaju strateški i pozorno upravljati situacijama čekanja kako bi iste rezultirale njihovom koristi.

Svaka organizacija koja izravno komunicira sa svojim klijentima, suočava se s pitanjima repova čekanja. Poboljšanje zadovoljstva klijenata je ključni čimbenik upravljanja repovima čekanja, a uslužna poduzeća to sve više i više prepoznaju, obraćajući pozornost i uvodeći dobro promišljene promjene u uslužne sustave. Pružanje visoke razine kvalitete usluge je pravi cilj učinkovitog upravljanja repovima čekanja. 
Na kraju ovoga rada može se zaključiti da je uloga čekanja studenata u percipiranoj kvaliteti usluga studentske referade i dalje vrlo neistražena tema. Pregledom dostupne literature može se uvidjeti kako je vrlo malo znanstvenika provelo istraživanja na tu temu i da se većina literature sastoji od mišljenja stručnjaka i analiza slučajeva. Iako je takve literature mnogo, ona ne nudi konkretan odgovor na glavno pitanje ovoga rada, a to je utječe li vrijeme čekanja na percipiranu kvaliteta usluga. Ovaj rad nudi odgovor na to pitanje u empirijskome dijelu gdje se na temelju istraživanja ukazuje na povezanost vremena čekanja sa zadovoljstvom pruženim uslugama i time daje doprinos ovoj neistraženoj temi.

U ovome radu potvrđeno je da je vrijeme čekanja povezano sa zadovoljstvom uslužnim sustavom iako model nije signifikantan. Operativne karakteristike za vrijeme trajanja mjerenja sustava čekanja referade pokazuje da je referada primjereno organizirana, što se može dodatno potkrijepiti visokom prosječnom ocjenom zadovoljstva korisnika (studenata) od 4,5 na dobivanje usluge od studentske referade Ekonomskog fakulteta u Zagrebu.

\section{LITERATURA}

1. Bielen, F., Demoulin, N. (2007.), Waiting time influence on the satisfaction-loyalty relationship in services, Managing Service Quality: An International Journal, 17(2): 174-193.

2. Davis, M. M., Heineke, J. (1994.), Understanding the Roles of the Customer and the Operation for Better Queue Management, International Journal of Operations \& Production Management, 14(5): 21-34.

3. Davis, M. M., Maggard, M. J. (1990.), An analysis of customer satisfaction with waiting times in a two-stage service process, Journal of Operations Management, 9(3): 324-34.

4. Durrande-Moreau, A. (1999.), Waiting for service: ten years of empirical research, International Journal of Service Industry Management, 10(2): 171-194.

5. Fitzsimmons, J. A., Fitzsimmons, M. J. (2008.), Service management : operations, strategy, information technology, McGraw-Hill-Irwin, Boston.

6. Fullerton, G., Taylor, S. (2015.), Dissatisfaction and violation: two distinct consequences of the wait experience, Journal of Service Theory and Practice, 25(1): 31-50.

7. Heizer, J., Render B., Munson, C. (2017.), Operations Management: Sustainability and Supply Chain Management, Pearson, Boston.

8. Hensley, R. L., Sulek, J. (2007.), Customer satisfaction with waits in multi-stage services, Managing Service Quality: An International Journal, 17(2): 152-173.

9. Jones, P., Peppiatt, E. (1996.), Managing perceptions of waiting times in service queues, International Journal of Service Industry Management, 7(5): 47-61.

10. Jouini, O., Dallery, Y. and Nait-Abdallah, R. (2008), Analysis of the impact of team-based organizations in call center management, Management Science, 54(2): 400-414.

11. Lee, W., Lambert, C. U. (2005.), The effect of waiting time and affective reactions on customers' evaluation of service quality in a cafeteria, Journal of Foodservice Business Research, 8(2): 19-37. 
12. Lovelock, C., Gummesson, E. (2004.), Whiter services marketing? In search of a new paradigm and fresh perspectives, Journal of Service Research, 7(1): 20-41.

13. Maister, D. (1985.), The Psychology of Waiting Lines, http://davidmaister.com/articles/the-psychology-of-waiting-lines/, pristupljeno: 10. 6. 2016.

14. McDonnell, J. (2007.), Music, scent and time preferences for waiting lines, International Journal of Bank Marketing, 25(4): 223-237.

15. McGuire, K. A., Kimes, S. E., Lynn, M., Pullman, M. E., Lloyd, R. C. (2010.), A framework for evaluating the customer wait experience, Journal of Service Management, 21(3): 269-290.

16. Morse, P. M. (1963.), Queues, inventories and maintenance : the analysis of operational systems with variable demand and supply by Philip M. Morse, J. Wiley \& Sons, New York.

17. Mueller, A. L. (2000.), On the waiting times in queues with dependency between interarrival and service times, Operations research letters, 26(1): 43-47.

18. Pawlowski, A. (2008.), Queuing psychology: Can waiting in line be fun?, http://edition.cnn.com/2008/TECH/science/11/20/queuing.psychology/, pristupljeno: 10. 6 . 2016.

19. Sarel, D., Marmorstein, H. (1998.), Managing the delayed service encounter: the role of employee action and customer prior experience, The Journal of Services Marketing, 12(3): 195-206.

20. Sheu, C., McHaney, R., Babbar, S. (2003.), Service process design flexibility and customer waiting time, International Journal of Operations \& Production Management, 23(8): 901-917.

21. Shi, J., Erdem, E., Peng, Y., Woodbridge, P., \& Masek, C. (2015). Performance analysis and improvement of a typical telephone response system of VA hospitals: a discrete event simulation study, International Journal of Operations \& Production Management, 35(8): 1098-1124.

22. Taylor, S. (1994.), Waiting for Service: The Relationship between Delays and Evaluations of Service, The Journal of Marketing, 58(2): 56-69.

23. Wexler, M. N. (2015.), Re-thinking queue culture: the commodification of thick time, International Journal of Sociology and Social Policy, 35(3/4): 165-181.

24. Zhao, X., Hou, J., Gilbert, K. (2014.), Measuring the variance of customer waiting time in service operations, Management Decision, 52(2): 296-312.

25. Zourrig, H., Chebat, J. C. (2009.), Waiting in a queue with strangers and acquaintances, International Journal of Quality and Service Sciences, 1(2): 145-159. 